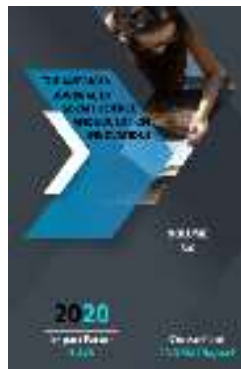

Journal Website: http://usajournalshub.c om/index,php/tajssei

Copyright: Original content from this work may be used under the terms of the creative commons attributes 4.0 licence.

\section{Modern Pedagogical - Psychological Factors For The Formation Of A Healthy Lifestyle Thinking Among Young Generation}

\author{
Siddikov Elyorjon Bakhromjonovich \\ Teacher Of General Secondary Educational School No.33 Of Furkat District Of Fergana Region, \\ Independent Researcher, Uzbekistan
}

\title{
ABSTRACT
}

The article analyzes about the pedagogical-psychological problems of attitudes to health as a value in young generation, the formation of health culture and components of a healthy lifestyle, modern trends in health pedagogy.

\section{KEYWORDS}

Youth, health, health care, physical fitness, healthy living, healthy lifestyle, health pedagogy.

\section{INTRODUCTION}

At the heart of innovative changes in the system of education and upbringing in the world is rapidly developing health pedagogy ("health care"), aimed at maintaining human health. The physical and mental health and vitality of the population determine the level of civilization of the state and reflect the sustainable development of the nation. In this regard, it is important to form a mindset and the need to maintain good health in humans, there is an increase in the volume of research that serves to ensure pedagogical effectiveness in public health infrastructure. In the world, health is one of the fundamental individual and social values that lead to the future socio-economic and cultural 
development of mankind and the well-being of society. The value of health and a healthy lifestyle is enshrined in the Charter of the World Health Organization (1948), the Ottawa Charter on Health Promotion (1986), and the Bangkok Charter on Health Promotion in a Globalized World (2005) [1]. The strategic potential of the attitude to health as a value is the study of the optimal directions of its maintenance on a global scale, at the level of the state and individuals, the dissemination of experiences in this area is a pedagogical problem.

In pedagogical and psychological research around the world, the priority of studying the attitude of the individual to health as a value arises due to changes in modern human lifestyle and the high incidence of chronic diseases. The importance of studying the social and psychological factors of human lifestyle [2] is related to the ability to prevent or reduce the risk of various diseases and deaths by changing human behavior. As a value to health to effectively promote a healthy lifestyle and implement training in it the need for a systematic study of the socio-psychological determinants of the relationship, there is a need for a modern scientific approach to this research and scientific-practical problem.

\section{MATERIALS AND METHODS}

In the sciences of pedagogy and psychology, there are three areas of understanding the attitude to health as a value: 1) sociological (I.V.Juravleva, 2006; S.S.Gordeeva, 2011 and others); 2) humanistic-personality (SM Heidrich, S.D.Ryff, 1995; A.E.Sozontov, 2003; P. Miquelon, R.J. Vallerand, 2006; N. A. Shmoylova, 2007, 2099; I. A. Alikin, N. V. Lukyanchenko and others, 2008; A. A.Pashin, 2014 and others.); 3) socio-psychological understanding of attitudes to health (A. Baum, J. Singer, S. Taylor, 1984; D.R. Rutter; L. Quine, 1994; I.N.Gurvich, 1998, 1999; G. S.Nikiforov, 2006; T.V.Belinskaya, 2005; R. A. Berezovskaya, 2010, 2011; L.A.Svetkova, I. N. Gurvich, 2012 and others). The attitude of the individual to health as a value, the peculiarities of his youth in the study of pedagogical and psychological factors in the formation of a healthy lifestyle, special attention will be paid to the role of social support and social isolation for human health.

Attitudes of Uzbek scientists to health in the context of valeology (Sh. B. Irgashev, 2008 [3]), the formation of a healthy lifestyle through health technologies (D. Sharipova, A. Musurmanova, M. Tairova, 2005 [4]; D. Sharipova and others., 2011 [5], 2015 [6]; N. K. Svetlichnaya, 2015 [7]; O. R. Jamoldinova, 2015 [8]) and in relation to the need for lifestyle changes in chronic diseases (e.g., E. Abduganieva and others 2015 [9])4.

\section{ANALYSIS AND RESULTS}

Particular attention is paid to health care in Uzbekistan, the existence of a regulatory framework in this area, the improvement of the institutional and reserve framework for medical services, the country is implementing measures to reform the health care system and social protection of citizens. The "Strategy of actions on five priority areas of further development of the Republic of Uzbekistan for 2017-2021" identifies as important tasks for the development of the social sphere [10]. For the effective implementation of these tasks, it is necessary to systematically study the sociopsychological factors that shape the attitude of the individual, especially young people to health as a value.

In the world education system, the health of the younger generation is respected as a national value of any nation, and this issue is approached as an important socio-pedagogical task, as well as the prospects of the state and there is a growing need for scientific research on the nation's gene pool, economic, intellectual, anthropogenic potential in the development of the country, its demographic support, the issues that determine the development of society.

This includes constructive and preventive technologies aimed at improving the health of 
young people, the introduction of systematic and integrated models in the educational process, the use of invariant-stratified technologies to protect students from the effects of harmful habits and about the issues of improving a new approach, attitude, attitude, essence, form, criteria, demand to the content of the rational organization of valeological and prophylactic activities of educational institutions, social institutions, family and individual are of particular importance.

The introduction of a healthy lifestyle in the country is an important link in the reform of the education system, which is now a priority of the development strategy of our country. During the years of independence, the state program "For a Healthy Generation" has become a priority of state policy. The subject "Valeology" is taught in higher education institutions. Measures are being taken to improve physical culture and sports. In recent years, fundamental changes have taken place in the field of medicine. 7-year development concept for radical reform of the medical system until 2025, more than 130 normative and legal acts in the field of public health have been adopted for implementation.

This, in turn, serves to carry out targeted research on the formation of thinking and the need to protect the health of the population. Hence, it is shown that the structure of an individual's attitude to health as a value includes cognitive, emotional, and behavioral components, the complex interactions between which are determined by health value. A similar understanding of the phenomenon of "attitude to health as a value" is a scientific study of it is also the basis for ensuring the effectiveness of sociopsychological programs to promote a healthy lifestyle.

Systematic understanding of the scope of socio-psychological research of attitudes to health includes 1) understanding of the role of socio-demographic, socio-economic, socio- cultural factors in the transition to a healthy lifestyle; 2) distinguish the advantages of the characteristics of the cognitive, emotional or behavioral components; 3 ) analysis of healthoriented actions; 4) reveal the role of various psychological characteristics (for example, self-efficacy, control loci, personality traits); 5) to determine its characteristics in relation to the basic characteristics of individuals who are given and those who are not given a healthy lifestyle (adolescents, students or the elderly, representatives of various professional groups, in difficult life situations, different nosologies or individuals with a specific state of health).

Recently, there is a process of understanding such concepts as health, health care, healthy lifestyle, healthy thinking as a historical-social, philosophical-psychological, moral-aesthetic category. Because the health care process is a multifaceted concept, its components and requirements are very broad and multifaceted. Existing research in Uzbekistan includes "health", "lifestyle", "healthy lifestyle", "healthy culture", "hygienic education", "health values", "health protection", "health principles", valeology, "healthy thinking". there are a number of approaches that have attempted to shed light on the social, medical, and pedagogical nature of medical knowledge.

The ultimate goal of deciding on a healthy lifestyle and way of thinking, a healthy upbringing system is to form a healthy generation. "Bringing up a healthy generation," M.Kholmatova writes, "means building the foundation of a great state, the foundation of a prosperous life. The upbringing of a healthy generation combines two aspects - the upbringing of the younger generation to be physically healthy and their spiritual development".[11]

So, the main criterion of a healthy lifestyle is high spirituality. If the processes of selfknowledge, self-formation, and the development of one's abilities are reflected in spirituality in family relations, in the relationship between man and society, then 
we will see that a healthy lifestyle has been established at the same time.

It should be noted that the idea of physical perfection and mental endurance as a component of human lifestyle is considered one of the lifelong values of society. From ancient times, philosophers and medical theorists have considered the free activity of man as a basic condition of perfection.

Despite the great attention paid to the problem of health, the concept of "health" has not found its full concrete scientific definition in the Uzbek philosophical and cultural literature. In the modern scientific and philosophical literature we can observe a variety of approaches in its description. Most scholars argue that there is still no single, universally accepted, scientifically based concept of "individual health".

\section{Directions Of Health Pedagogy}

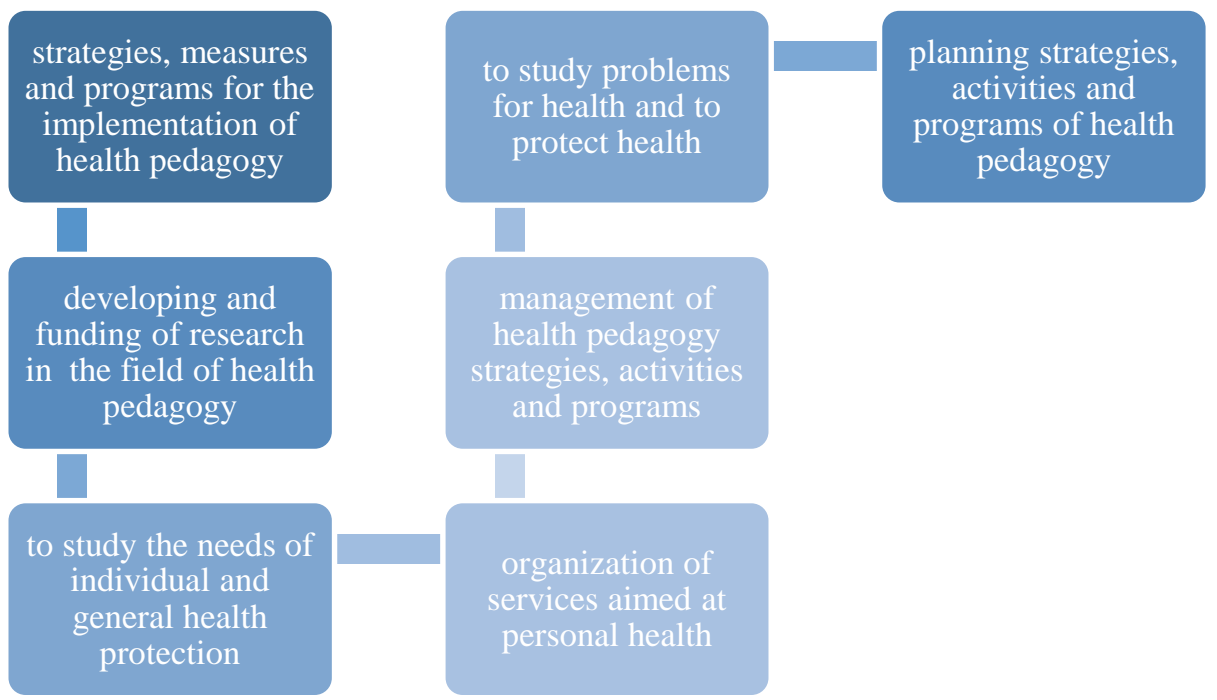

Features of the development of perceptions of health, a methodologically valuable consequence arising from the sociopsychological criteria of teaching young people a healthy lifestyle; socio-psychological mechanisms for the formation of behaviors aimed at maintaining and strengthening health (for example, the influence of adults and peers on health attitudes); the importance of practicing decision-making skills in lifethreatening life situations (e.g., smoking, firsttime alcohol, drug use) and the ability to think through an action plan and systematically review its implementation.

In girls and boys, where the cognitive, emotional, and behavioral components of attitudes toward health are more assimilated, was more pronounced in women and individuals belonging to the second stage of puberty.

Socio-psychological flexibility of the person, a high degree of flexibility in him, acceptance of himself and others, manifested in emotional comfort, can participate during adolescence, adolescence, and adulthood as a determinant of an individual's attitude toward health as a value.

Describing the social stress experienced during adolescence and adolescence in school, can serve as a basis for succumbing to unhealthy behaviors. 
Socio-cognitive, motivational and managerial characteristics of a person, manifested in high indicators of self-efficacy, the internality of the health control locus, the belief that health depends on significant other people, participates as a socio-psychological determinant of cognitive, emotional, and especially behavioral components of attitudes as a value to an individual's health, both during adolescence and adolescence and in adulthood.

\section{CONCLUSION}

The idea of educating a spiritually and physically healthy generation has a historical character, it is formed as a vital need with the emergence of humanity, and its content is improving. In particular, the religious views that emerged as a social need (animism, fitism, totemism, Buddhism), the sacred book of Zoroastrians, the Avesto, important sources of Islamic culture is Korani Karim, the Hadith, examples of folklore, as well as in the works of our great scholars such as Hidoya, Laws of Medicine, it is emphasized that a healthy life is a guarantee of a healthy mind, an important factor in the health of society, and people are called to live a healthy life.

Secondly, it is important to inculcate in young people the ideas of developing a culture of healthy living in the socio-political, philosophical, historical, ethnographic, pedagogical, psychological, legal, medical and other scientific and methodological literature through the content of in-class and out-of-class educational work. is important.

Thirdly, the foundation of physical fitness in the development of a healthy generation must be built on spiritual maturity. An important index that determines the formation of "health care" in young people is the spiritual culture.

\section{REFERENCES}

1. The Bangkok Charter for Health Promotion in a Globalized World // Official website of the World Health Organization.
URL: http://www. who. Int / conferences (date of the application:10.10.16); Ottawa Charter for Health Promotion, 1986 // Official site of the Regional Office for Europe of the World Health Organization. date of the application: URL: http://www.euro.who.int/_data/assets

(date of the application: 10.10.16); Charter (Constitution) of the World Health Organization [Electronic resource] // Website of the World Health Organization. URL: http://who.int/ru/ (date of the application: 15.12.2016); The Bangkok Charter for Health Promotion in a Globalized World// Official website of the World Health Organization. URL: http://www.who.int/healthpromotion/con ferences/ (date of the application: 10.10.16)

2. Health issues [Electronic resource] // Website of the World Health Organization. URL: http://who.int/ru/ (date of the application: 15.12.2017).

3. Irgashev Sh. B. Modern trends in the formation of a healthy lifestyle among the population. Fundamentals of valeology. Study guide. T., 2008.32 p.

4. Sharipova D. D., Musurmanova A., Tairova $M$. Formation of a healthy lifestyle. $T$.: UzGIFK, $2005.180 \mathrm{p}$.

5. Sharipova D., Sharipov A., Shakhmurova $G$. The teacher's readiness to implement health-preserving knowledge and the formation of a healthy lifestyle in the system of lifelong education // Education throughout life: lifelong education for sustainable development. 2011.P. 304-306;

6. Sharipova D. D., Shakhmurova G. A., Sharipov A. D. Health-preserving orientation of education is one of the important vectors of lifelong education // Education throughout life: lifelong education for sustainable development. 2015. No. 2. P.489-492; 
7. Svetlichnaya N.K. Formation of a healthy lifestyle. T .: "Tafakkur qanoti”, 2015.140 p ;

8. Jamoldinova O. R. Improving pedagogical mechanisms for the implementation of the principles of continuity and continuity in the development of a culture of healthy life of youth: abstract of the thesis.... doct. pedagogical sciences, 13.00.01 - Theory and history of pedagogy. Management in education (pedagogical sciences). Tashkent, 2015;

9. Abduganieva E.A., Khalmukhammedova S.M., Dadabaeva R.K. Influence of lifestyle changes and dietary patterns on the quality of life of patients with COPD // Features of the formation of a healthy lifestyle: factors and conditions: materials of the III International Scientific and Practical Conference ( May 2015) / otv. ed. Yu. Yu. Shurygina. Ulan-Ude: VSGUTU Publishing House, 2015.374 p. P.3-5.

10. The order of the President of the Republic of Uzbekistan No. PF-4947 "On the Strategy of Actions for the Further Development of the Republic of Uzbekistan" dated February 7, 2017 // Collection of Legislation of the Republic of Uzbekistan, 2017, No. 6, Article 70, No. 20, Article 354, No. 23, Article 448, No. 37, Article 982.

11. Kholmatova M. Culture of family relations and upbringing of a healthy generation. $T$ . Uzbekistan, 2000 - P. 20

12. Yakovleva N.V. Analysis of approaches to the study of health in psychology // Psychology and practice. Yearbook of the Russian Psychological Society. Yaroslavl, 1998, Vol. 4. Issue 2. P.364-366. 